Vol. 3, No. 1, 2021

https://doi.org/10.23939/jtbp2021.01.106

Volodymyr Bidos ${ }^{1}$, Taras Markiv ${ }^{2}$, Serhiy Solodkyy $^{1}$

\title{
MECHANICAL PROPERTIES OF CEMENT CONCRETES INCORPORATING GROUND TIRE RUBBER
}

\author{
Lviv Polytechnic National University, \\ ${ }^{I}$ Department of Highways and Bridges, \\ ${ }^{2}$ Department of Building Production \\ volodymyr.bidos.mnbd.2019@lpnu.ua
}

(C) Bidos V., Markiv T., Solodkyy S., 2021

This article proves the possibility of replacing aggregates in concrete mixtures with rubber, which is obtained by grinding of used car tires. It was found that the replacement of crushed coarse aggregate in the amount of $10 \mathrm{vol}$. \% with ground rubber from used car tires increases the bending strength by $23 \%$ The compressive strength does not change significantly.

When working in the subcritical stage of deformation (until the macrocrack shifts), concrete with the replacement of the coarse aggregate, is preferred, as the energy consumption of which for elastic deformation $\left(W_{e}\right)$ exceeds the base concrete.

Analysis of the supercritical stage of deformation (macrocrack propagation) reveals that the replacement of fine and coarse aggregates negatively affects the value of total energy consumption for local static deformation in the main crack zone $\left(\mathrm{W}_{1}\right)$, which is by 1.35 and 1.14 times lower than the control concrete.

Key words: Cement concrete, rubber, ground tire rubber, fine aggregate, coarse aggregate, crack resistance, compressive strength, tensile strength in bending.

\section{Introduction}

The utilization of industrial waste in concrete mixtures for several decades is a promising option for the disposal of waste and related industrial products. Materials such as tires require specialized landfills, but can be recycled and used in concrete production while providing additional benefits to the properties of concrete. The use of these materials in concrete has obvious advantages, and therefore, instead of disposing of this waste, they are sold, thus providing additional savings. The use of recycled tires in concrete production can provide many life cycle benefits more than traditional additional concrete materials. The biggest advantage of using recycled tire aggregates in concrete is not direct material savings, but rather its impact on the properties of concrete and analysis of its life cycle. The main advantage of using recycled tire aggregates is the proximity of manufacturers. Tire processing plants are available in and around large metropolitan areas, resulting in lower transportation costs compared to natural aggregates that can be transported by road or rail for use in urban concrete structures.

The use of ground tire rubber in concrete can result in the reduction of its strength. The main reason for the lack of strength is cracking, which occurs due to the fact that the loads exceed the strength of concrete. Stresses arising in concrete can be interpreted by external forces (poor support of the of the base, cyclic stress from the movement of cars; increased axle load of cars), as well as for internal forces due to physicochemical processes that occur when concrete hardens.

Most often, internal cracking occurs by shrinkage of the newly laid concrete mixture, which is due to the hardening processes in the initial period and during the first 24 hours by rapid evaporation of water after laying and compaction of concrete. First of all, cracks may be invisible, but gradually become noticeable after the full concrete's strength set or cracks expansion to the appearance of visible defects 
under the action of these external loads in concrete. Most often, such cracks appear all over the concrete and disrupt the overall appearance of the structure before the concrete begins to gain design strength.

\section{Target of this article}

The purpose of the study: to investigate the effect of fine and coarse aggregates replacement with ground tire rubber on the strength and crack resistance of concrete.

Research objectives are:

- to analyze the advantages of partial aggregates replacement with ground tire rubber compared to conventional cement concrete;

- to analyze the impact of aggregates replacement with different fraction of ground tire rubber on concrete fracture properties;

- to determine the most effective fraction of ground tire rubber for concrete.

\section{Analysis of recent research and publications}

Tire production for vehicles is increasing exponentially due to the rapidly growing population and transportation development. Substantial rubber waste is produced from used tires which pass their service life. Raffoul et al. (Raffoul, 2017; Katelyn, 2018; Muñoz-Sánchez, 2017; Pacheco-Torres, 2018; Grinys, 2012) stated that tire waste is nearly proportional to tire production. The world's yearly tire production exceeded 2.9 billion tires. This massive amount of non-biodegradable waste occupies a large area and causes environmental hazards. Burning or using tire as fuel may produce toxic gases that are harmful for environment and may cause destructive pollution of natural air .

Tire rubber contains styrene, a strongly toxic component that is highly hazard to humans. Therefore, dumping of waste tires may be very dangerous to human health. Recycling of waste in any way is beneficial. In recent years, researchers have attempted to establish a proper guideline for recycling tire waste in different ways In response to the growing environmental concerns, waste tires are now being recycled in a manner that not only benefits the environment but also contributes to economic growth.

A decrease in compressive strength by $30-63 \%$ can occur when 5-20\% of the aggregate in concrete is replaced with rubber crumb. Thomas and Gupta (Thomas,2015; Thomas,2016) concluded that replacing $12.5 \%$ of aggregate in concrete with rubber is optimal for better resistance to water absorption and carbonization, as well as to achieve moderate compressive strength. Senin et al. (Senin, 2017) recommended not to exceed $20 \%$ of the rubber content in concrete

\section{Techniques used}

Portland cement CEM I 42.5 was used in this study. Commercially available PCE based superplasticizer was used in the researches. Rubber crumbs of $0-5 \mathrm{~mm}$ and tire chips of 5-10 $\mathrm{mm}$ fractions were used for aggregate replacement.

Three concrete mixtures were designed, mix proportions are shown in Table 1 (W/C=0.6).

Each series of concretes consisted of cube samples measuring $10 \times 10 \times 10 \mathrm{~cm}$ and prisms measuring $10 \times 10 \times 40 \mathrm{~cm}$. The concrete mix was prepared in the labotatory concrete pan mixer ATEK-1150. The rubber has been treated with $10 \% \mathrm{NaOH}$ solution for 24 hours.

The compressive and bending strength were determined according to standards (DSTU B B.2.7-214: 2009 and DSTU B B.2.7-187: 2009). Research and calculation of fracture characteristics of concrete were performed in accordance with standard (DSTU B B.2.7-227: 2009) and methods of Solodkyy S. Y. (Solodky, 2008; Solodky, 2014; Solodky, 2017). 
Table 1

\section{Concrete mix proportions}

\begin{tabular}{|c|c|c|c|c|c|c|c|c|c|}
\hline 芠 & 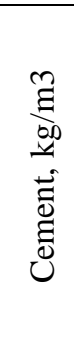 & 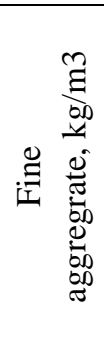 & 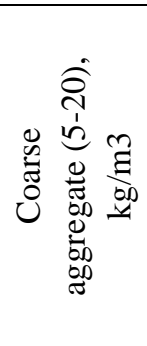 & 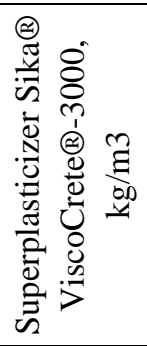 & 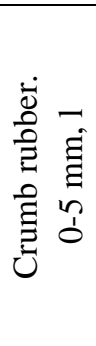 & 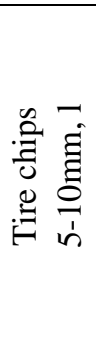 & $\frac{0}{3}$ & $\begin{array}{l}\text { हี } \\
\text { 言 } \\
\text { ज }\end{array}$ & 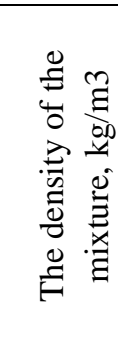 \\
\hline 350CR0TC0 & 350 & 670 & 1150 & 3.5 & & & 0.6 & 140 & 2380 \\
\hline 350CR10 & 350 & 603 & 1150 & 3.5 & 47 & & 0.6 & 150 & 2330 \\
\hline $350 \mathrm{TC} 10$ & 350 & 670 & 1035 & 3.5 & & 84 & 0.6 & 160 & 2290 \\
\hline
\end{tabular}

The compressive and bending strength are shown in Fig. 1 and Fig. 2, respectively.

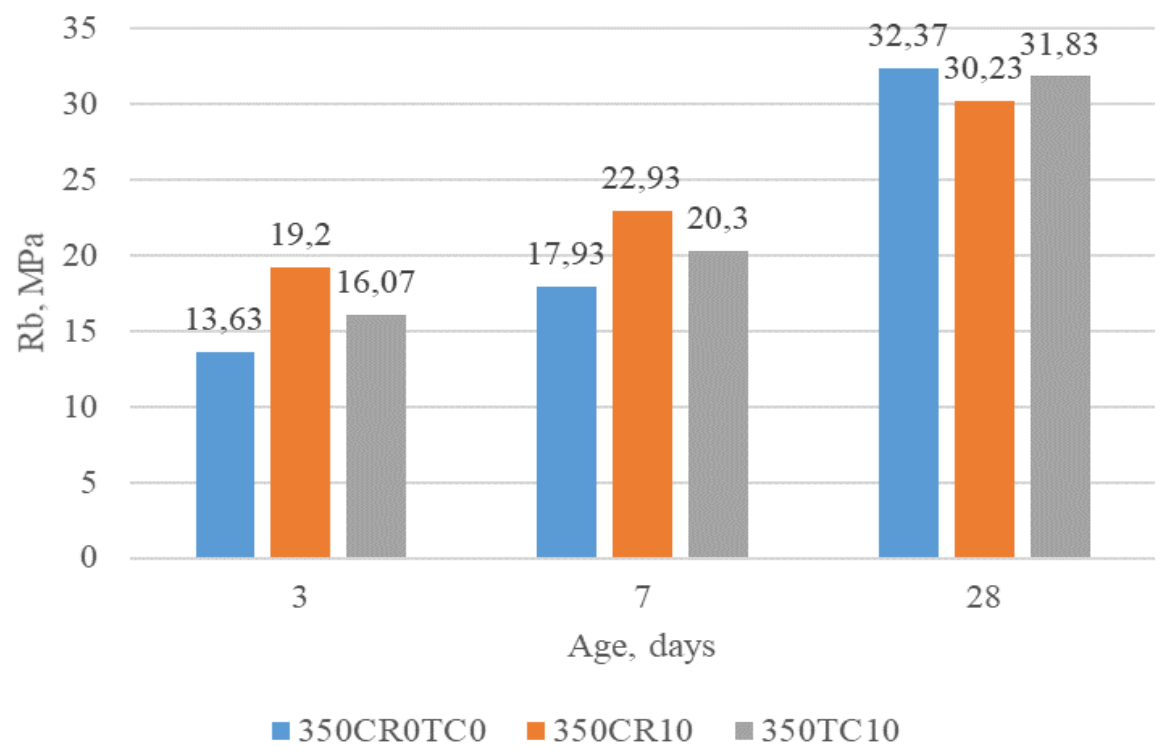

Fig. 1. Compressive strength of concretes

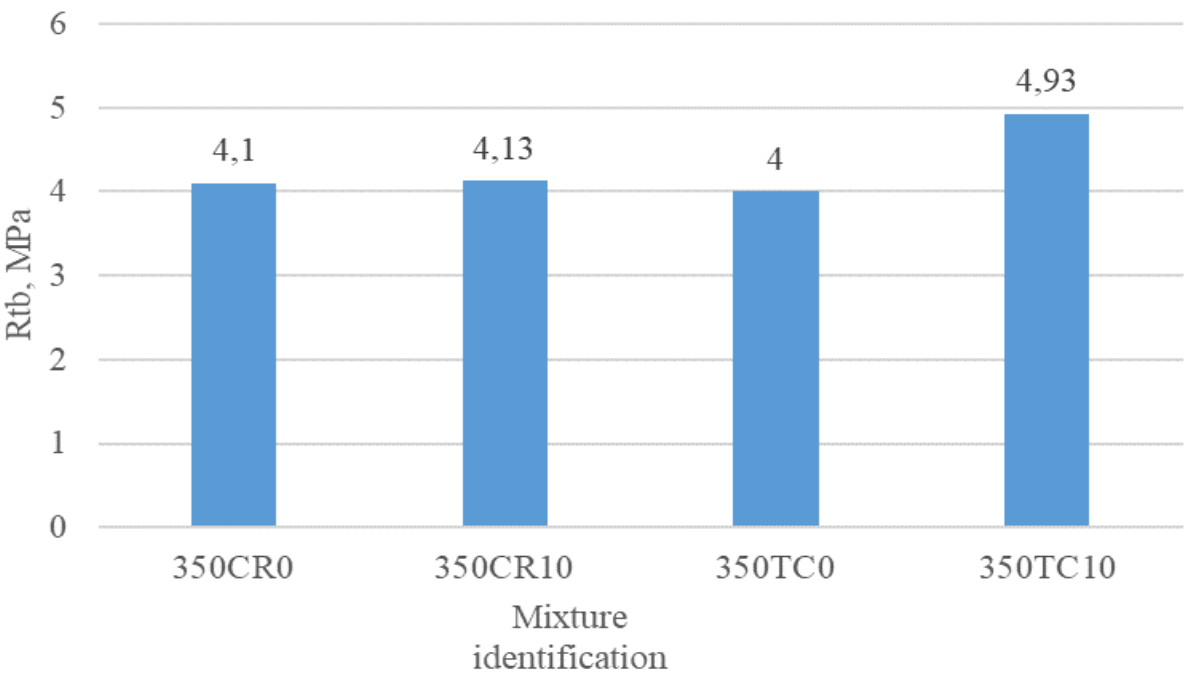

Fig. 2. The bending strength of concretes 
After analyzing the obtained results (Fig. 1 and Fig. 2), it was found that the replacement of coarse aggregate by products of tire processing (fr. $5-10 \mathrm{~mm}$ ) in the amount of $10 \mathrm{vol} . \%$ results in the increasing the bending strength of concrete by $23 \%$. Compressive strength doesn't differ significantly. Replacement of fine aggregate by tire processing products $(\mathrm{fr} .0-5 \mathrm{~mm})$ in the amount of $10 \mathrm{vol}$. \% does not change the bending strength in comparison with the control concrete. However, the compressive strength increases by 40 and $27 \%$ after 3 and 7 days of hardening, respectively, but the slight decrease of compressive strength by approximately $7 \%$ is observed after 28 days.

The results of the research of the strength characteristics and deformability of concrete are given in Table 2.

Table 2

Physico-mechanical characteristics of concretes

\begin{tabular}{|c|c|c|c|c|c|}
\hline $\begin{array}{c}\text { Mixture } \\
\text { identification }\end{array}$ & $\begin{array}{c}\text { Compressive } \\
\text { strength } \\
\mathrm{f}_{\mathrm{c} \text {.cube, } \mathrm{MPa}}\end{array}$ & $\begin{array}{c}\text { Bending } \\
\text { strength } \mathrm{f}_{\mathrm{ctfm}}, \\
\mathrm{MPa}\end{array}$ & $\begin{array}{c}\text { Static design modulus } \\
\text { of elasticity of } \\
\text { concrete } \mathrm{E}_{\mathrm{b}}, \mathrm{MPa}\end{array}$ & $\begin{array}{c}\text { Flexural } \\
\text { modulus of } \\
\text { elasticity of } \\
\text { concrete } \mathrm{E}_{\mathrm{tb}} \cdot 103, \\
\mathrm{MPa}\end{array}$ & $\begin{array}{c}\text { The criterion } \\
\text { of fragility } \\
\mathrm{X}_{\mathrm{tb}} \cdot 10-4, \mathrm{M}\end{array}$ \\
\hline 350CR0TC0 & 32.36 & 5.45 & 42 & 2702 & 278 \\
\hline 350CR10 & 30.23 & 6.36 & 34 & 3613 & 303 \\
\hline 350TC10 & 31.83 & 4.99 & 29 & 2841 & 307 \\
\hline
\end{tabular}

The complete state diagram (CSD) of control and concrete with rubber content is shown in Fig. 2. Power and energy characteristics of the studied concretes are given in Table 3.

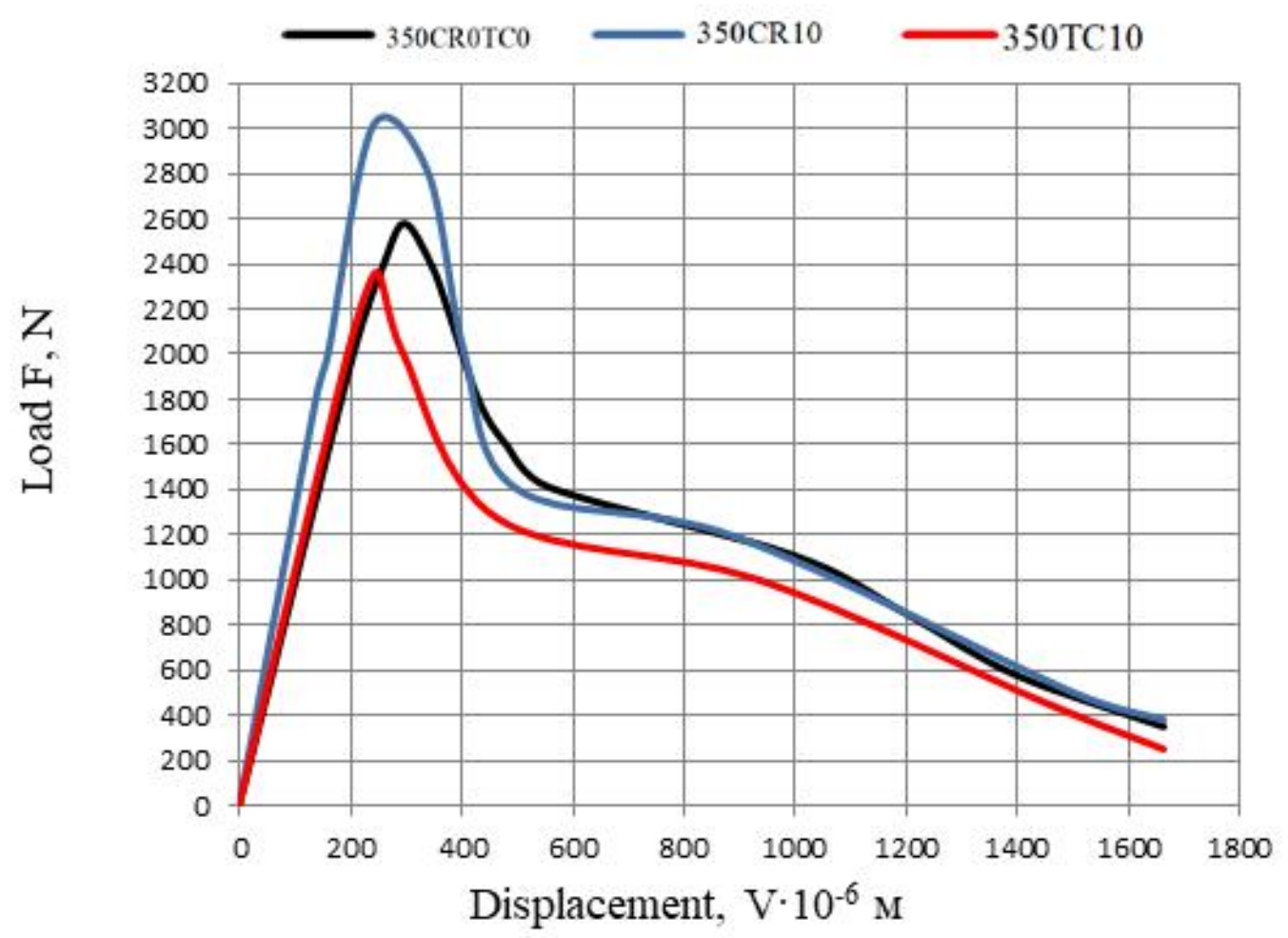

Fig. 3. Complete diagram of the condition of the studied concretes 350CROTCO - control concrete; 350CR10 - concrete incorporating crumb rubber; $350 T C 10$ - concrete containing tire chips 
Power and energy characteristics of crack resistance of concrete

\begin{tabular}{|c|c|c|c|c|c|c|c|c|c|c|c|c|c|}
\hline 离 & 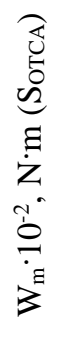 & 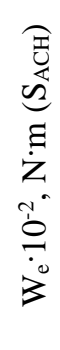 & 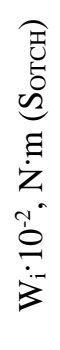 & 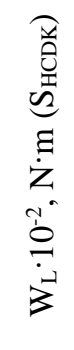 & 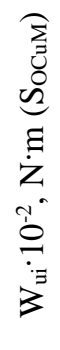 & 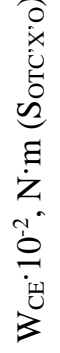 & 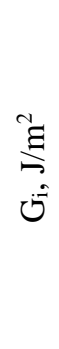 & $\begin{array}{l}\hat{\Xi} \\
\hat{\Xi}\end{array}$ & 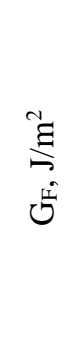 & 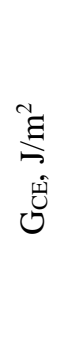 & $\underset{\stackrel{N}{E}}{\stackrel{\mathcal{F}}{-}}$ & 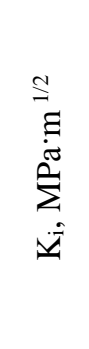 & 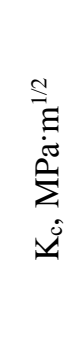 \\
\hline 350CR0TC0 & 8 & 34 & 42 & 150 & 17 & 18 & 70 & 250 & 306 & 30 & 42 & 0.43 & 0.28 \\
\hline $350 \mathrm{CR} 10$ & 3 & 35 & 37 & 169 & 17 & 13 & 62 & 282 & 340 & 22 & 34 & 0.47 & 0.28 \\
\hline $350 \mathrm{TC} 10$ & 4 & 27 & 31 & 134 & 13 & 5 & 51 & 224 & 269 & 8 & 29 & 0.38 & 0.15 \\
\hline
\end{tabular}

The analysis of the supercritical stage of deformation (Fig.3 and table 3) reveals the advantage of control concrete and concrete incorporating tire chips. The value of total energy consumption for local static deformation in the area of the main crack (Wl) is by 1.19, 1.35 times higher than the concrete containing crumb rubber.

\section{Conclusions}

1. Recycled tire particles can be incorporated into concretes and mortars by replacing fine and coarse aggregates. The advantage of utilizing rubber crumb in cement mortars and concretes is: reducing $\mathrm{CO}_{2}$ emissions, saving the environment.

Pre-treatment of rubber crumb with alkali $\mathrm{NaOH}$ has a positive effect on the nature of the interaction between the rubber crumb and cement stone by removing a zinc shell from the surface of rubber particles, and hence on the strength and crack resistance of concrete.

2. Replacement of coarse aggregate by tire processing products fr. $5-10 \mathrm{~mm}$ in the amount of 10 vol. \% increases the bending strength of concrete by $23 \%$, compressive strength doesn't change significantly..

3. Replacement of fine aggregate by tire processing products (fr. $0-5 \mathrm{~mm}$ ) in the amount of 10 vol. $\%$ does not change the bending strength. The compressive strength decreases by $7 \%$ compared to the control concrete.

4. In the subcritical stage of deformation (ascending branch of the concrete condition diagram), concrete incorporating rubber crumb has a slight advantage, which is confirmed by energy consumption for elastic deformation (We), which exceeds the control concrete by $3 \%$.

5. Analysis of the supercritical stage of deformation (descending branch of the concrete condition diagram) reveals the advantage of concretes with the replacement of coarse aggregate.:The values of total energy consumption for local static deformation in the main crack zone (Wl) exceed the control concrete by $13 \%$. The values of total energy consumption for local static deformation in the area of the main crack $\left(\mathrm{W}_{\mathrm{l}}\right)$ of concrete with the replacement of fine aggregate are less than the control concrete by $12 \%$.

6. The fracture toughness $(\mathrm{Ki})$ increases in sequence: concrete incorporating tire chips, control concrete, concrete containing crumb rubber.

7. The research shows that in addition to the environmental effect, the replacement of aggregates in concrete with rubber crumbs of different fractions can improve the strength and crack resistance of concrete.

\section{References}

Raffoul S., Garcia R., Escolano-Margarit D., Guadagnini M., Hajirasouliha I., Pilakoutas K., (2017) Behaviour of unconfined and FRP-confined rubberised concrete in axial compression, Constr. Build. Mater. 147 388-397, https://doi.org/10.1016/j.conbuildmat.2017.04.175. 
Katelyn A. Stallings, Stephan A. Durham \& Mi G. Chorzepa (2018): Effect of cement content and recycled rubber particle size on the performance of rubber-modified concrete, International Journal of Sustainable Engineering, DOI: $10.1080 / 19397038.2018 .1505971$

Thomas B. S., Gupta R. C. (2015). Long term behaviour of cement concrete containing discarded tire rubber, J. Clean. Prod. 10.2 P. 78-87, https://doi.org/10.1016/j.jclepro.2015.04.072.

Thomas B. S., Chandra Gupta R. (2016). Properties of high strength concrete containing scrap tire rubber, J. Clean. Prod. 113. P. 86-92, https://doi. org/10.1016/j.jclepro.2015.11.019.

Senin M. S., Shahidan S., Abdullah S. R., Guntor N. A., Leman A. S., (2017). A review on the suitability of rubberized concrete for concrete bridge decks, IOP Conf. Ser. Mater. Sci. Eng. 271, https://doi.org/10.1088/1757899X/271/1/ 012074012074.

Zhang Z., Ma H., Qian S. (2015). Investigation on properties of ECC incorporating crumb rubber of different sizes, J. Adv. Concr. Technol. 13. P. 241-251, https://doi.org/10.3151/jact.13.241.

Azevedo F., Pacheco-Torgal F., Jesus C., Barroso de Aguiar J. L., Camões A. F. (2012). Properties and durability of HPC with tyre rubber wastes, Constr. Build. Mater. 34. P. 186-191, https://doi.org/10.1016/ j.conbuildmat. 2012.02.062.

Muñoz-Sánchez B., Arévalo-Caballero M. J., Pacheco-Menor M. C. (2017). Influence of acetic acid and calcium hydroxide treatments of rubber waste on the properties of rubberized mortars, Mater. Struct. 70-75, https://doi.org/10.1617/s11527-016-0912-7.

Pacheco-Torres R., Cerro-Prada E., Escolano F., Varela F. (2018). Fatigue performance of waste rubber concrete for rigid road pavements, Constr. Build. Mater. 176, 539-548, https://doi.org/10.1016/ j.conbuildmat.2018.05.030.

Grinys, H. Sivilevic ius, M. Daukšys (2012). Tyre rubber additive effect on concrete mixture strength, J. Civ. Eng. Manag. 18 393-401, https://doi.org/ 10.3846/13923730.2012.693536.

Gesoglu M., Güneyisi E., Khoshnaw G., Ipek S. (2014). Investigating properties of pervious concretes containing waste tire rubbers, Constr. Build. Mater. 63 206-213, https://doi.org/10.1016/j.conbuildmat.2014.04.046.

Topçu I. B., Demir A. (2007). Durability of Rubberized Mortar and Concrete, J. Mater. Civ. Eng. 19 173178, https://doi.org/10.1061/(ASCE)0899-1561 (2007) 19:2(173).

Topçu I. B., Unverdi A. (2018). Scrap tires/crumb rubber, in: Waste Suppl. Cem. Mater. Concr., Elsevier. P. 51-77, https://doi.org/10.1016/B978-0-08- 102156-9.00002-X.

Krishna C. Baranwal (2003). Akron rubber development laboratory, astm standards \& testing of recycle rubber, in: Rubber Div. Meet. Am. Chem. Soc., San Francisco, California.

Solodkyy S. Y. (2008). Crack resistance of concrete on modified cements. Monograph. NU LP Publishing House $144 \mathrm{p}$.

Solodkyy S. Y., Turba Y. V. (2014). Experimental and statistical modeling of crack resistance of concretes reinforced with polypropylene fiber. Scientific notes. Interuniversity collection. - Lutsk, issue 46, p. 512-515.

Solodkyy S. Y., Turba Y. V. (2017). Increasing the crack resistance of dispersed reinforced polypropylene fiber concrete by technological factors. Bulletin of the Odessa State Academy of Civil Engineering and Architecture. issue 66. P. 99-105.

В. М. Бідось ${ }^{1}$, Т. С. Марків ${ }^{2}$, С. Й. Солодкий ${ }^{1}$ Національний університет “Львівська політехніка”,

${ }^{1}$ кафедра автомобільних доріг та мостиів,

${ }^{2}$ кафедра будівельного виробництва

\section{МЕХАНІЧНІ ВЛАСТИВОСТІ ЦЕМЕНТНИХ БЕТОНІВ ІЗ ВМІСТОМ ГУМИ}

(C) Бідось В. М., Марків Т. С., Солодкий С. Й., 2021

Виробництво шин для транспортних засобів зростає в геометричній прогресії у зв'язку 3 швидким збільшенням кількості населення та розвитком транспорту. Оскільки щорічне виробництво шин у світі перевищило 2,9 млрд шин (2017р.), можна уявити масштаби відповідних відходів, а також темпи їх накопичення. Відходи, що не розкладаються біологічно, займають значну територію та спричиняють екологічну небезпеку. 
Використання шин як палива може спричинити викиди токсичних газів, які шкідливі для навколишнього середовища та можуть істотно забруднювати повітря. Введення відходів промисловості у бетонні суміші вже кілька десятиліть є перспективним варіантом утилізації відходів і супутніх продуктів промисловості. Такі матеріали, як шини, потребують спеціалізованих звалищ, проте можуть перероблятись і використовуватись у виробництві бетону, за одночасно забезпечуючи додаткові переваги властивостям бетону. Найбільшою перевагою використання перероблених заповнювачів з шин у бетоні $є$ не тільки економія матеріалу, але і їх вплив на властивості бетону.

У статті доведено можливість заміни заповнювачів у бетонних сумішах гумою, яка отримана подрібнення відпрацьованих автомобільних шин. Встановлено, що заміна щебеню в кількості 10 об. \% гумою з відпрацьованих автомобільних шин збільшує міцність на розтяг при згині на $23 \%$, міцність на стиск практично не змінюється.

Під час роботи в докритичній стадії деформування (до моменту зрушування макротріщини) перевагу проявляє бетон із заміною крупного заповнювача, енерговитрати якого на пружне деформування (We) перевищують показник базового бетону.

Аналіз закритичної стадії деформування (поширення макротріщини) виявляє, що заміна дрібного і крупного заповнювачів негативно впливає на значення загальних енерговитрат на локальне статичне деформування в зоні магістральної тріщини (Wl), які є у 1.35 i 1.14 разу відповідно нижчими, ніж у бетонів базової серії.

В'язкість руйнування (Кi) зростає в послідовності: бетон із заміною крупного заповнювача, бетон базової серії, бетон із заміною дрібного заповнювача.

Ключові слова: цементобетон, гума, матеріали подрібнення віддпрацьованих автомобільних шин, дрібний заповнювач, крупний заповнювач, тріщиностійкість, міцність на стиск, міцність на розтяг при згині. 